\title{
STRATEgI PEMASARAN JAGUNG HASIL PENGEMBANGAN UPSUS PAJALE DI KABUPATEN MAMUJU
}

\author{
Zulfiani Effendi, Ahmad Ramadhan Siregar, Sitti Nurani Sirajuddin \\ Universitas Hasanuddin (UNHAS) Makassar Sulawesi Selatan, Indonesia \\ Email: zulfiani.effendi@gmail.com, ahmadramadhan_siregar@yahoo.com, \\ sitti_nurani@yahoo.co.id
}

\begin{abstract}
Abstrak
Penelitian ini bertujuan untuk menganalisis faktor-faktor yang mempengaruhi pemasaran jagung hasil pengembangan UPSUS PAJALE di Kabupaten Mamuju dan merumuskan alternatif dan prioritas strategi yang dapat diterapkan dalam pemasaran jagung hasil pengembangan UPSUS PAJALE di Kabupaten Mamuju. Penelitian ini dilaksanakan di Kecamatan Tommo, Kabupaten Mamuju, Sulawesi Barat. Responden dalam Penelitian ini di tentukan secara purposive sampling dengan mewawancarai tiga puluh tiga informan yang juga adalah responden. Penelitian ini adalah penelitian deskriptif kualitatif yang didukung oleh data kuantitatif. Penelitian ini mengidentifikasi faktor internal dan eksternal yang kemudian dianalisis dengan menggunakan matriks internal eksternal (IE). Hasil dari matriks IE digunakan sebagai rujukan untuk menyusun strategi pemasaran dengan menggunakan matriks SWOT. Alternatif strategi pemasaran yang diperoleh kemudian dianalisa menggunakan QPSM untuk menentukan prioritas strategi yang akan dijalankan. Hasil penelitian menunjukkan Matriks IE (Internal Eksternal) berada di sel $\mathrm{V}$ yaitu Konsentrasi melalui Integrasi Horizontal. Strategi ini kemudian dirumuskan di Matriks SWOT dan menghasilkan tujuh strategi pemasaran. Strategi tersebut dianalisa menggunakan QSPM dan diperoleh strategi prioritas untuk pemasaran jagung hasil UPSUS PAJALE di Kabupaten Mamuju yaitu mendorong terbentuknya BUMD yang bergerak untuk memanfaatkan produk jagung sehingga bisa menjadi stabilisator bagi harga jagung atau mendorong investasi dan menumbuhkan industri yang menggunakan jagung sebagai bahan utamanya.
\end{abstract}

Kata Kunci: strategi pemasaran, jagung, analisis SWOT

\section{Abstract}

This study aims to analyze the factors that influence the marketing of corn from the UPSUS PAJALE development in Mamuju Regency and to formulate alternative and priority strategies that can be applied in marketing the corn produced by UPSUS PAJALE development in Mamuju Regency. This research was conducted in Tommo District, Maтuju Regency, West Sulawesi. Respondents in this study were determined by purposive sampling by interviewing thirty-three informants who were also respondents. This research is a qualitative descriptive study supported by quantitative data. This study identifies internal and external factors which are then

$\begin{array}{ll}\text { How to cite: } & \text { Effendi, Zulfiani., Ahmad Ramadhan Siregar, Sitti Nurani Sirajuddin (2021) Strategi Pemasaran Jagung } \\ & \text { Hasil Pengembangan Upsus Pajale Di Kabupaten Mamuju. Syntax Literate: Jurnal Ilmiah Indonesia. 6(7). } \\ & \text { http://dx.doi.org/10.36418/ syntax-literate.v6i7.3513 } \\ \text { E-ISSN: } & \text { 2548-1398 } \\ \text { Published by: } & \text { Ridwan Institute }\end{array}$


analyzed using an internal external matrix (IE). The results of the IE matrix are used as a reference for developing a marketing strategy using the SWOT matrix. The alternative marketing strategy obtained is then analyzed using QPSM to determine the priority of the strategy that will be carried out. The results showed that the IE (Internal External) Matrix was in cell $V$, namely Concentration through Horizontal Integration. This strategy is then formulated in the SWOT Matrix and produces seven marketing strategies. The strategy was analyzed using QSPM and a priority strategy was obtained for marketing the corn from UPSUS PAJALE in Mamuju Regency, namely Encouraging the formation of BUMDs that move to utilize corn products so that they can become stabilizers for corn prices or encourage investment and grow an industry that uses corn as its main ingredient.

Keywords: marketing strategy; corn; SWOT analysis

\section{Pendahuluan}

Jagung merupakan produk pangan strategis yang bernilai ekonomis dan berpotensi untuk dikembangkan karena posisinya sebagai sumber utama karbohidrat dan protein setelah beras. Selain itu jagung juga digunakan sebagai bahan baku pakan ternak, bahan baku industri dan rumah tangga. Dalam beberapa tahun terakhir, kebutuhan jagung terus meningkat sejalan dengan laju pertumbuhan penduduk dan kebutuhan akan pakan ternak yang terus meningkat. Sebagian besar produksi jagung nasional digunakan sebagai pakan ternak, sisanya digunakan untuk konsumsi pangan dan untuk kebutuhan industri lain dan memenuhi kebutuhan penggunaan benih.

Kementerian Pertanian telah merumuskan kebijakan untuk mewujudkan ketahanan pangan di Indonesia dalam bentuk swasembada beras, jagung, dan produk kedelai yang berkelanjutan. Program swasembada yang dicanangkan pemerintah dikenal dengan Program Upsus Pajale (upaya khusus padi, jagung dan kedelai) yang berlangsung dari tahun 2015 hingga sekarang. Dalam petunjuk pelaksanaan yang dibuat (Badan Penyuluhan dan Pengembangan SDM Pertanian, 2015) di sebutkan program ini merupakan strategi dan upaya peningkatan luas tanam dan produktivitas untuk tanaman padi, jagung dan kedelai di sentra produksi pangan di Indonesia. Program Upsus pajale diharapkan dapat mewujudkan ketahanan pangan di Indonesia melalui kegiatan Rehabilitasi Jaringan Irigasi Tersier (RJIT), penyediaan peralatan dan mesin pertanian, penyediaan dan penggunaan benih unggul, penyediaan dan penggunaan pupuk berimbang, pengaturan musim tanam, dan pelaksanaan Gerakan Penerapan Tata Kelola Tanaman Terpadu (GPPTT). Produksi usaha tani jagung untuk kabupaten Mamuju mengalami peningkatan lebih dari 100\% setiap tahunnya sejak dari 2015 sampai 2018 sejak adanya Program UPSUS Pajale (Badan Pusat Statistik, 2020). Untuk tahun 2019, produksi usaha tani jagung mengalami penurunan disebabkan oleh pengurangan bantuan oleh pemerintah baik bantuan bibit, bantuan pupuk maupun alat dan mesin pertanian. Peningkatan produktivitas usaha tani jagung yang berakibat pada peningkatan produksi yang sangat signifikan tentu saja menciptakan tantangan dalam penyerapan hasil produksi jagung tersebut. Sistem pemasaran jagung hasil produksi dari petani harus bisa terserap dengan baik dan memberi keuntungan yang memuaskan bagi petani 
agar motivasi dalam mengembangkan produksi jagung tetap terjaga atau semakin meningkat. Hasil penelitian (Syamsuddin dan Rahmawati, 2015) menemukan bahwa belum ada kemitraan petani dengan pedagang yang terjalin dengan baik sehingga pemasaran hasil belum mendapatkan jaminan penjualan setelah dilakukan panen dalam penelitiannya di Provinsi Sulawesi Barat.

Pertumbuhan produksi jagung di Kabupaten Mamuju menunjukkan tren yang sangat tinggi hingga lebih dari 100\% setiap tahunnya dari 2015 sampai dengan 2018 sejak adanya program Upsus Pajale. Data produksi dapat dilihat di tabel 1.

Tabel 1

Trend pertumbuhan produksi jagung sejak tahun 2015 - 2019 di Kabupaten Mamuju

\begin{tabular}{|c|c|c|c|}
\hline Tahun & $\begin{array}{c}\text { Luas Panen } \\
\text { (Ha) }\end{array}$ & $\begin{array}{c}\text { Poduktivitas } \\
\text { (Kw/Ha) }\end{array}$ & $\begin{array}{l}\text { Produksi } \\
\text { (Ton) }\end{array}$ \\
\hline 2015 & 5.706 & 48,91 & 27.906 \\
\hline 2016 & 20.508 & 48,96 & 100.412 \\
\hline 2017 & 41.990 & 48,96 & 205.578 \\
\hline 2018 & 51.745 & 88,35 & 457.164 \\
\hline 2019 & & & $406.384,65$ \\
\hline
\end{tabular}

(BPS Mamuju dalam angka, 2015-2020)

Jenis jagung yang ditanam sebagian besar adalah jenis hibrida yang digunakan oleh industri pakan ternak untuk bahan utama pakan di Makassar, Peternak Ayam Petelur dan industri lainnya. Sebagian besar jagung di Kabupaten Mamuju dikirim ke Kompleks Pergudangan di KIMA Makassar, sebagian lagi dikirim ke Peternak Ayam Petelur di Sidrap, untuk Industri di Kalimantan, dan juga ada yang dikirim ke Nusa Tenggara Timur lewat pelabuhan di Kabupaten Bone. Beberapa masalah yang terjadi dilapangan adalah petani tidak memiliki kemampuan dalam penetapan harga karena adanya keterikatan petani kepada pedagang pengumpul dengan adanya kontrak antara petani dan pedagang pengumpul dimana biaya yang dikeluarkan selama budidaya ditanggung oleh pedagang pengumpul yang berakibat harga pembelian ditentukan oleh pedagang sehingga petani tidak bisa mendapatkan hasil maksimal dari hasil panen jagung yang diusahakannya. Harga untuk bulan Agustus tahun 2020 ditingkat petani berada di Rp. 2000-2.500/Kg berbeda dengan tingkat harga dalam Permendag No.7/2020 yang dipatok di angka Rp.3.150/Kg untuk kadar air 15\% sementara untuk kadar air $20 \%$ harga acuan di patok Rp. 3.050/Kg. Harga yang rendah tentu saja akan berpengaruh terhadap minat petani dalam menanam jagung karena penurunan pendapatan dalam usaha tani yang dilakukannya.

Dari uraian tersebut, kendala utama yang dihadapi saat ini adalah petani jagung seharusnya dapat memasarkan produksi dengan nilai yang lebih tinggi. Pemerintah daerah seharusnya membantu dengan kebijakan yang dapat meningkatkan pendapatan petani jagung minimal petani jagung tidak dirugikan sehingga kesejahteraan petani jagung bisa lebih ditingkatkan. Penelitian ini dilaksanakan dengan tujuan untuk menganalisis faktor-faktor yang mempengaruhi pemasaran jagung hasil pengembangan UPSUS PAJALE di Kabupaten Mamuju dan merumuskan alternatif dan prioritas 
strategi yang dapat diterapkan dalam pemasaran jagung hasil pengembangan UPSUS PAJALE di Kabupaten Mamuju.

\section{Metode Penelitian}

Penelitian ini dilaksanakan di Kecamatan Tommo, Kabupaten Mamuju. Penentuan lokasi dilakukan secara sengaja (purposive) dengan pertimbangan bahwa Kecamatan Tommo merupakan salah satu sentra produksi usahatani jagung di Kabupaten Mamuju, Propinsi Sulawesi Barat. Penelitian ini dilaksanakan pada bulan Oktober-Januari dan olah data dilakukan di bulan Februari. Teknik pengumpulan data yang dilakukan dalam penelitian ini adalah tekhnik wawancara yaitu teknik pengumpulan data yang dilakukan secara langsung dengan responden berpedoman pada daftar pertanyaan (kuesioner) yang telah dibuat, observasi yang merupakan pengumpulan data dengan mengadakan pengamatan langsung pada objek penelitian untuk memperoleh data yang diperlukan dan yang terakhir studi pustaka yaitu teknik pengumpulan data yang dilakukan dengan mempelajari referensi yang berkaitan dengan penelitian.

Responden terdiri dari 33 orang yang memiliki peran dalam pemasaran jagung di Kabupaten Mamuju, yaitu:

a) Lima Orang Pedagang Jagung (pedagang besar atau pedagang kecil) dengan minimal 3 tahun dalam menjalankan usaha jual beli jagung.

b) Sepuluh Orang Ketua Kelompok Usaha Tani jagung yang masih aktif dengan jumlah anggota minimal 15 orang dan sudah terbentuk selama minimal 3 tahun.

c) Lima Belas Orang Petani jagung luas lahan minimal 1/4 Ha dan pengalaman dalam usaha tani jagung minimal 5 tahun.

d) Tiga orang pengambil kebijakan: 1). Dinas yang membidangi fungsi tanaman pangan 2). Pakar dari akademisi yang menggeluti jagung 3). Petugas lapangan dari dinas yang membidangi fungsi tanaman pangan

Penelitian ini adalah penelitian deskriptif kualitatif yang didukung oleh analisa kuantitatif yang bertujuan menentukan lingkungan internal dan eksternal yang mempengaruhi usaha pemasaran jagung hasil pengembangan UPSUS PAJALE di Kabupaten Mamuju dan menentukan alternatif strategi yang bisa dijalankan serta memperoleh strategi prioritas untuk dijalankan (Sugiyono, 2017). Tujuan dari penelitian ini di proses melalui 3 model pendekatan, yaitu:

1. Tahap Input

Pada tahap ini peneliti menggunakan identifikasi faktor internal utama dan faktor eksternal utama kemudian melakukan pembobotan dari setiap faktor faktor yang berkisar 0.0 (tidak penting) hingga 1.0 (sangat penting). Jumlah dari pembobotan harus sama dengan 1.0. Penentuan bobot akan dilakukan dengan menggunakan metode "paired comparison" (Kinnear dan Taylor, 2003). Penggunaan metode ini untuk memberikan penilaian terhadap bobot setiap faktor internal dengan skala 1, 2 dan 3, dimana: (1): Jika indikator horizontal kurang penting daripada indikator vertikal, (2): Jika indikator horizontal sama penting 
dengan indikator vertikal dan (3) = Jika indikator horizontal lebih penting daripada indikator vertical.

2. Tahap Pencocokan

a. Matriks IE (Internal Eksternal)

Pada tahap ini, Matriks IFE (kekuatan dan kelemahan) diberi nilai rating menggunakan rating antara 1 sampai 4 masing-masing faktor yang memiliki nilai: rating 1=Sangat Lemah, rating $2=$ Tidak Begitu Lemah, $3=$ rating Cukup Kuat, dan rating $4=$ Sangat Kuat. Pemberian peringkat pada matriks EFE (peluang dan ancaman) menggunakan skala: $1=$ rendah (respon di bawah ratarata), $2=$ sedang (respon rata-rata), $3=$ tinggi (respon di atas rata-rata), dan 4= sangat tinggi (respon superior).

Bobot dengan rating atau peringkat dikalikan untuk mendapatkan nilai skor pembobotan. Jumlah skala pembobotan untuk memperoleh total skor pembobotan bagi perusahaan. Skor bobot total 1,00 hingga 1,99 mempresentasikan posisi internal yang lemah, skor 2,00 hingga posisi rata-rata, dan skor 3,00 hingga posisi 4,00 posisi kuat. Skor rata-rata adalah 2,5. Jika nilainya di bawah 2.5 menunjukkan bahwa secara internal perusahaan lemah, sedangkan nilai di atas 2.5 menunjukkan posisi internal yang kuat. Nilai total ini menunjukkan bagaimana perusahaan bereaksi terhadap faktor strategis internal (David \& David, 2016). Berikut ini adalah penjelasan mengenai strategi yang terdapat pada sel Matriks IE menurut (Rangkuti, 2013), yaitu:

1. Sel I: konsentrasi dengan integrasi vertikal.

2. Sel II dan V: konsentrasi dengan integrasi horizontal

3. Sel III: Kembali. Strategi ini cocok untuk perusahaan dengan daya tarik industri yang tinggi, ketika masalah perusahaan sudah mulai dirasakan tetapi belum kritis. Strategi ini direalisasikan oleh perusahaan dengan cara mengurangi operasional perusahaan.

4. Sel IV: stabilitas

5. Sel VI: Disinvestasi

6. Sel VII: Diversifikasi konsentris

7. Sel VIII: Diversifikasi Konglomerat. Strategi pertumbuhan melalui aktivitas bisnis yang tidak terkait dapat dilaksanakan jika perusahaan menghadapi posisi kompetitif yang tidak terlalu kuat dan nilai daya tarik industrinya sangat rendah.

8. Sel IX: Kebangkrutan atau likuiditas. Likuidasi adalah strategi yang dilakukan dengan menjual sebagian atau seluruh perusahaan atau produk perusahaan yang ada, dengan tujuan memperoleh uang untuk melunasi seluruh kewajiban perusahaan dan kemudian menyerahkan kepada pemegang saham lainnya. 
Tabel 2

Tabel Skor Bobot Matriks IE

\begin{tabular}{|c|c|c|c|c|}
\hline 4.0 & $\begin{array}{c}\text { Kuat } \\
3.0-4.0\end{array}$ & $\begin{array}{c}\text { Rata-Rata } \\
2.0-2.99 \\
\end{array}$ & Lemah 1.0-1.99 & 1.0 \\
\hline $\begin{array}{l}\text { Tinggi } \\
3.0-4.0\end{array}$ & $\begin{array}{c}\mathrm{I} \\
\text { Integrasi }\end{array}$ & $\begin{array}{c}\text { II } \\
\text { Integrasi }\end{array}$ & \multirow{2}{*}{ III ${ }_{\text {Around }}^{\text {Turn }}$} & \\
\hline 3.0 & Vertikal & Horizontal & & \\
\hline $\begin{array}{l}\text { Sedang } \\
2.0-2.99\end{array}$ & \multirow{2}{*}{$\begin{array}{c}\text { IV } \\
\text { Stabilty }\end{array}$} & $\begin{array}{c}\mathrm{V} \\
\text { Integrasi }\end{array}$ & \multirow{2}{*}{$\begin{array}{c}\text { VI } \\
\text { Divestasi }\end{array}$} & \\
\hline 2.0 & & Horizontal & & \\
\hline Rendah & VII & VIII & IX & \\
\hline $1.0-1.99$ & Diversifikasi & Diversifikasi & Bangkrut/ & \\
\hline 1.0 & Konsentris & Konglomerat & Likuiditas & \\
\hline
\end{tabular}

b. Matriks SWOT

Setelah melakukan identifikasi faktor internal dan eksternal serta menentukan posisi saat ini dengan matriks Internal Eksternal (IE) maka ditentukan anternatif alternatif strategi yang bisa digunakan dengan matriks SWOT. Matriks ini memiliki prinsip dasar yaitu memaksimalkan kekuatan dan peluang serta meminimalkan kelemahan dan ancaman dengan empat bidang alternatif strategi, yaitu Strategi SO, Strategi WO, Strategi ST dan Strategi WT.

\section{Tabel 3}

Matriks SWOT

\begin{tabular}{|c|c|c|}
\hline Eksternal & $\begin{array}{l}\text { STRENGTH (S) } \\
\text { Daftar kekuatan }\end{array}$ & $\begin{array}{l}\text { WEAKNESS }(W) \\
\text { Daftar kelemahan }\end{array}$ \\
\hline OPPORTUNITIES (O) & STRATEGI SO & STRATEGI WO \\
\hline Daftar Peluang & $\begin{array}{l}\text { Gunakan kekuatan } \\
\text { untuk memanfaatkan } \\
\text { peluang }\end{array}$ & $\begin{array}{l}\text { Minimalkan kelemahan } \\
\text { untuk memanfaatkan } \\
\text { peluang }\end{array}$ \\
\hline THREATS (T) & STRATEGI ST & STRATEGI WT \\
\hline Daftar Ancaman & $\begin{array}{l}\text { Gunakan kekuatan } \\
\text { untuk mengatasi } \\
\text { ancaman }\end{array}$ & $\begin{array}{l}\text { Minimalkan kelemahan } \\
\text { dan menghindari ancaman }\end{array}$ \\
\hline
\end{tabular}

Sumber: (David RF, 2012)

3. Tahap Keputusan

Tahap terakhir penentuan strategi bauran pemasaran adalah tahap pengambilan keputusan yaitu penentuan strategi prioritas berdasarkan analisis daya tarik strategi alternatif. QSPM adalah teknik analisis yang dirancang untuk menentukan daya tarik relatif dari ukuran alternatif yang layak dengan memberi peringkat pada strategi pemasaran untuk mendapatkan daftar prioritas.

(David RF, 2012) mengungkapkan Analisis QSPM memungkinkan ahli strategi untuk mengevaluasi strategi alternatif. Langkah-langkah yang harus diikuti untuk membuat QSPM adalah:

a. Membuat daftar faktor kunci peluang dan ancaman eksternal serta faktor kunci kekuatan dan kelemahan internal perusahaan di kolom kiri QSPM.

b. Memberi bobot pada setiap faktor penentu keberhasilan eksternal dan internal. Bobot ini identik dengan yang digunakan dalam matriks EFE dan IFE. 
c. Mengevaluasi matriks fase 2 (pencocokan) dan mengidentifikasi alternatif strategis yang harus dipertimbangkan untuk diterapkan oleh perusahaan.

d. Tentukan Nilai daya tarik (Attractiveness Score) atau AS, yang didefinisikan sebagai angka yang menunjukkan daya tarik relatif dari setiap strategi dalam satu set alternatif tertentu. Kisaran nilai daya tarik adalah $1-4$, di mana $1=$ tidak menarik, 2 = agak menarik, 3 = cukup menarik dan 4 = sangat menarik.

e. Menghitung Skor Ketertarikan Total (Total Attraction Score-TAS) dengan mengalikan bobot dengan nilai kemenarikan di setiap baris. Semakin tinggi nilai total attractiveness, semakin menarik alternatif strategi tersebut.

f. Hitung jumlah dari nilai total daya tarik. Tambahkan Skor Ketertarikan Total ke setiap kolom strategi di QSPM. Jumlah total nilai daya tarik (STAS) menunjukkan strategi mana yang paling menarik dari setiap alternatif strategis. QSPM diilustrasikan pada Tabel 4.

Tabel 4

Matriks QSPM

\begin{tabular}{|c|c|c|c|c|c|}
\hline \multirow{2}{*}{$\begin{array}{c}\text { Faktor-faktor } \\
\text { kunci }\end{array}$} & \multirow{2}{*}{ Bobot } & Strategi 1 & Strategi 2 & \multicolumn{2}{|c|}{ Strategi 3} \\
\hline & & TAS & $\begin{array}{ll}\text { AS } & \text { TAS }\end{array}$ & $\mathbf{A S}$ & TAS \\
\hline $\begin{array}{l}\text { Faktor-faktor } \\
\text { kunci internal }\end{array}$ & & & & & \\
\hline $\begin{array}{l}\text { Faktor-faktor } \\
\text { kunci eksternal }\end{array}$ & & & & & \\
\hline $\begin{array}{l}\text { Jumlah Nilai T } \\
\text { Tarik }\end{array}$ & & & & & \\
\hline
\end{tabular}

Sumber : David, 2017

Keterangan: $\quad$ AS $=$ Nilai daya tarik

TAS $=$ Total nilai daya tarik

\section{Hasil dan Pembahasan}

Jagung yang diusahakan oleh petani di Kabupaten Mamuju adalah jagung hibrida dan sebagian kecil jagung komposit. Jagung hibrida diusahakan untuk kepentingan komersil sedangkan Jagung komposit diusahakan oleh petani untuk tujuan konsumsi dan biasanya dibeli oleh pedagang sayur. Pertanaman jagung di Kabupaten Mamuju diusahakan sepanjang tahun.

Jagung hasil produksi petani di kabupaten Mamuju dipasarkan langsung ke pedagang pengumpul di Kecamatan. Seiring dengan meningkatnya persaingan antar pedagang pengumpul dalam memperoleh pasokan jagung, pedagang-pedagang tersebut menggunakan pola kemitraan untuk mengikat petani ketika menjual hasil panennya. Selain itu pedagang juga memanfaatkan jasa kolektor untuk langsung ke usahatani atau ke rumah-rumah petani untuk melakukan pembelian.

Produk dikembangkan berdasarkan kebutuhan dan keinginan pelanggan yang dilihat dari hasil riset pasar (Kotler, Kartajaya, \& Setiawan, 2017). Menurut (Titik, 2012), produk merupakan sesuatu yang dapat memenuhi keinginan dan kebutuhan pelanggan serta diperjualbelikan dengan tujuan untuk mendapatkan keuntungan. Untuk memenuhi standar kualitas yang diinginkan oleh pedagang grosir atau industri pakan, 
pengepul tetap menangani jagung yang mereka beli, baik yang dibeli langsung dari petani maupun dikumpulkan oleh pengepul, misalnya dengan menjemur kembali untuk memenuhi standar kadar air atau pembersihan ke memenuhi isinya. Setelah jagung dikumpulkan dan ditangani sesuai kebutuhan, pedagang melakukan penyimpanan hingga mencapai jumlah yang cukup untuk didistribusikan ke pedagang grosir atau industri pakan di kawasan industri Makassar, kawasan Sidrap, pulau Kalimantan, dan provinsi Kupang.

A. Identifikasi Faktor Kunci Sukses Kekuatan, Kelemahan, Peluang dan Ancaman

Strategi pemasaran jagung di rumuskan dengan memadukan faktor-faktor pada lingkungan internal Kabupaten Mamuju yang berada di dalam kewenangan pemerintah kabupaten untuk mengaturnya terkait kekuatan (strength) dan kelemahan (weakness) yang dimiliki dan lingkungan eksternal Kabupaten Mamuju yang berada di luar kewenangan pemerintah kabupaten untuk mengaturnya terkait peluang (opportunities) dan ancaman (threaths).

Analisis faktor internal bertujuan untuk mengetahui berbagai kekuatan dan kelemahan wilayah Mamuju dalam berbagai aspek yang terkait dengan pengembangan pemasaran produk jagung. Analisis faktor eksternal berupaya untuk mengetahui berbagai peluang yang dapat diperoleh wilayah Mamuju dalam berbagai aspek yang berkaitan dengan pengembangan jagung terutama dalam pemasarannya dan identifikasi ancaman yang merupakan faktor penghambat di luar kewenangan wilayah Mamuju di berbagai aspek yang terkait dengan pengembangan produk jagung, khususnya mengenai pemasarannya.

\section{Identifikasi Kekuatan dan Kelemahan}

a. Kekuatan

Kekuatan adalah kondisi internal yang menjadi pendorong keberhasilan meraih posisi unggul dalam menghadapi persaingan. Kekuatan yang dimaksud merupakan potensi sumberdaya dan kondisi yang dimiliki oleh Kabupaten Mamuju terkait dengan pengembangan komoditi jagung yang dapat dijadikan sebagai modal dasar dalam pemasaran komoditi jagung di Kabupaten Mamuju. Berikut merupakan faktor kekuatan pemasaran di Kabupaten Mamuju:

1) Tersedianya sarana perhubungan darat dan laut, sarana perhubungan yang tersedia dan lancar akan memudahkan proses mobilisasi komoditas pertanian khususnya komoditi jagung untuk Kabupaten Mamuju. Jalur darat tersedia dengan jalan aspal antar provinsi yang lancar dan ekspedisi yang selalu tersedia untuk digunakan sedangkan jalur laut bisa ditempuh dari pelabuhan belang belang atau pelabuhan budong - budong untuk akses ke pulau Kalimantan. Jalur darat digunakan untuk mobilisasi hasil panen jagung untuk memenuhi kebutuhan industri di Kawasan Industri Makassar, kebutuhan peternakan ayam di Kabupaten Sidrap dan memenuhi permintaan di Provinsi Nusa Tenggara Timur yang di drop di 
Pelabuhan Bone. Sedangkan jalur laut digunakan untuk mobilisasi hasil panen jagung untuk memenuhi kebutuhan industri di Kalimantan.

2) Ketersediaan lahan untuk pertanian jagung yang luas, luas panen jagung untuk Kabupaten Mamuju mengalami peningkatan drastis sejak adanya program UPSUS PAJALE yang diluncurkan oleh kementerian pertanian. Luas panen jagung di tahun 2015 yang hanya 5.706 Ha meningkat dengan cepat sehingga mencapai $51.745 \mathrm{Ha}$ di tahun 2018. Potensi penambahan lahan masih terbuka dengan masih banyaknya lahan gambut yang belum dimanfaatkan, perambahan hutan serta adanya alih fungsi lahan dari tanaman kakao ke tanaman jagung.

3) Jumlah produksi jagung yang tinggi, Kabupaten Mamuju adalah kabupaten di Provinsi Sulawesi Barat yang memiliki produktivitas jagung yang sangat tinggi. Pada tahun 2019 produksi jagung di Kabupaten mamuju mencapai 199.205,04 ton dengan luas tanam 45,669 Ha (BPS, Mamuju dalam Angka 2020) karena produksi yang sangat tinggi sehingga Kabupaten Mamuju dijadikan sentra unggulan jagung.

4) Banyaknya pedagang yang bergerak dalam pemasaran jagung, jagung di pasarkan oleh petani ke pedagang pengumpul atau pedagang besar selanjutnya pegadang besar memasarkan jagung pada konsumen antar pulau atau antar provinsi. Jumlah pedagang yang bergerak dalam pemasaran jagung tentu saja mempengaruhi harga pembelian jagung dari petani karena persaingan untuk memperoleh jagung dari petani cukup tinggi. (Kango, 2018) dalam penelitiannya juga menemukan bahwa harga dasar yang ada ditingkat petani sering dipermainkan oleh para tengkulak.

5) Kelompok tani yang mendukung, Kelompok tani di Kecamatan Tommo yang terdata oleh dinas yang membidangi pertanian sejumlah 261. Dengan luas wilayah $765,75 \mathrm{~km}^{2}$ Kecamatan Tommo memiliki area panen jagung seluas $13.176 \mathrm{Ha}$ (2019). Kelompok tani membantu petani dalam penyediaan informasi pasar dan pemasaran jagung secara kolektif.

6) Iklim yang sesuai, Jadwal penanaman jagung untuk Kecamatan Tommo tidak dipengaruhi oleh iklim sehingga penanaman dapat dilakukan di sepanjang tahun dengan waktu yang tidak serempak menyebabkan ketersediaan jagung bisa didapatkan sepanjang tahun. Kondisi ini tentu saja menguntungkan petani jagung karena lahan yang dikelolanya bisa memberikan hasil maksimal karena tidak ada waktu jeda panjang untuk ditanami kembali.

b. Kelemahan.

1) Prasarana jalan yang kurang memadai, kondisi jalan yang masih menjadi kendala dalam mobilisasi hasil panen jagung adalah jalan tani atau jalan yang menghubungkan kebun jagung sampai ke rumah petani serta jalan yang menghubungkan antar desa. Kondisi ini menyebabkan timbulnya 
biaya tambahan untuk pengangkutan karena pengangkutan hanya bisa dilakukan dengan menggunakan ojek motor.

2) Posisi tawar petani dalam penentuan harga jagung rendah, Keterbatasan modal yang dimiliki petani merupakan salah satu penghambat untuk petani membiayai kegiatan usahatani jagung mereka. Belum tersedianya lembaga-lembaga yang khusus seperti bank atau koperasi diperuntukkan kepada petani dalam mengatasi masalah keuangan tersebut menyebabkan petani bermitra dengan pedagang untuk pemberian modal menyebabkan petani dalam proses jual beli tidak memiliki kebebasan penuh dalam menentukan kepada siapa akan menjual hasil panennya sehingga harga jual hasil produksi jagung petani dibawah harga pasar. Hal ini juga ditemukan dalam penelitian (Ariusni \& Sentosa, 2018) dimana posisi tawar petani dalam pemasaran dinilai rendah sebagai kelemahan utama.

3) Rendahnya kualitas jagung hasil produksi petani, Rendahnya kualitas jagung hasil produkasi dari petani disebabkan oleh ketergantungan petani dengan bantuan hibah dari pemerintah yang memeiliki mutu standar dan rendahnya tingkat pengetahuan dan keterampilan dalam budidaya dan pascapanen. Proses pengeringan yang dilakukan petani masih mengandalkan sinar matahari sehingga pada saat jagung dipasarkan nilai tawar menjadi rendah karena petani menjual jagung kering panen.

4) Terbatasnya tingkat pengetahuan penerapan teknologi budidaya dan pascapanen, pengetahuan petani dalam menggunakan bibit unggul, penggunaan pupuk yang berimbang, penggunaan traktor serta pengendalian hama tanaman jagung masih terbatas. Cara yang digunakan selama ini masih bisa ditingkatkan efektifitasnya untuk mendapatkan produksi jagung yang lebih tinggi. Begitu juga dengan penanganan jagung pasca panen, petani belum memiliki pengetahuan yang memadai sehingga kehilangan hasil dari saat panen sampai pasca panen masih sering terjadi seperti belum adanya gudang penyimpanan pada saat harga rendah, lantai jemur maupun pemipil jagung. Penanganan pasca panen yang tepat diperlukan untuk meningkatkan nilai tambah, daya simpan jagung dan menekan kehilangan hasil.

5) Serangan OPT (Organisme Pengganggu Tanaman), Tikus umumnya menyerang tanaman jagung pada fase-fase pembentukan tongkol dan pengisian biji. Tongkol yang telah masak susu dimakan oleh tikus sehingga tongkol menjadi rusak dan mudah terinfeksi oleh jamur. Serangan hama tikus cukup merugikan petani di Kabupaten Mamuju, ada serangan yang bisa sampai menghabiskan buah jagung yang di tanam tanpa tersisa.

6) Belum adanya badan usaha pemerintah yang menangani pembelian jagung, Upaya pemerintah untuk menjaga stabilnya harga jagung belum maksimal dilakukan di Kabupaten Mamuju. Penentuan harga pembelian dari petani masih ditentukan oleh pedagang karena tidak ada PERDA di Kabupaten 
yang mengatur harga jagung. BUMN dan koperasi yang membeli jagung dari petani saat harga rendah juga tidak ada sehingga harga komoditi jagung di Kabupaten Mamuju belum bisa dijaga kestabilannya dalam meningkatkan kesejahteraan petani.

\section{Identifikasi Peluang dan Ancaman}

Dari analisis lingkungan eksternal yang dilakukan sebelumnya, dapat terlihat faktor-faktor apa saja yang ada dan dapat dikelompokkan menjadi faktor-faktor peluang dan faktor-faktor ancaman yang terdapat pada pemasaran jagung di kabupaten mamuju. Faktor-faktor tersebut adalah sebagai berikut:

a. Peluang

Faktor-faktor yang menjadi peluang pemasaran jagung di Kabupaten Mamuju berdasarkan analisis lingkungan eksternal terbagi menjadi lima. Berikut merupakan faktor-faktor yang menjadi peluang pemasaran jagung di Kabupaten Mamuju:

1) Kebutuhan pasokan pakan unggas dari jagung masih besar, usaha peternakan ayam petelur dan ayam broiler atau ayam pedaging semakin bertumbuh seiring dengan makin meningkatnya penduduk di Kabupaten Mamuju yang juga adalah ibukota Provinsi Sulawesi Barat. Meningkatnya usaha peternakan terutama unggas di Kabupaten Mamuju pada khususnya dan di Provinsi Sulawesi Barat pada umumnya tentu akan memberi pengaruh nyata terhadap meningkatnya permintaan untuk komoditi jagung sebagai bahan utama pakan ternak ayam.

2) Pengembangan industri pengolahan berbasis komoditi jagung, Melihat tingginya produksi jagung untuk Kabupaten Mamuju dimana ditahun 2019 bisa mencapai produksi sebanyak 406.384ton dan juga mempertimbangkan produksi dari kabupaten lain dimana total produksi jagung untuk Provinsi Sulawesi Barat ditahun 2019 mencapai 199.205,04 ton tentu saja sangat berpotensi untuk pengembangan industri pengolahan berbasis komoditi jagung.

3) Adanya dukungan dari pemerintah, Dalam pengembangan produksi pertanian terutama komoditi jagung di Kabupaten Mamuju tidak terlepas dari dukungan pemerintah kabupaten, provinsi dan pusat. Hal ini ditunjukkan lewat beberapa program yaitu UPSUS Pajale, program pengembangan kawasan tanaman pangan korporasi (ProPaktani), pendampingan petani serta memfasilitasi pengadaan bantuan dalam bentuk hibah untuk kebutuhan petani terutama untuk komoditi jagung memperlihatkan hasil yang sangat signifikan untuk meningkatkan produksi jagung di Kabupaten Mamuju.

4) Kualitas benih mempengaruhi harga, Benih jagung yang ditanam oleh petani saat ini sebagian besar adalah benih yang merupakan bantuan dari pemerintah. Kualitas dari benih yang diberikan oleh pemerintah dalam bentuk hibah belum bisa memberi kualitas maksimal untuk 
meningkatkan produktifitas dari petani jagung, penggunaan benih yang lebih baik dan tepat tentu akan memberi pengaruh nyata dalam peningkatan produktifitas dan kualitas jagung yang dihasilkan.

5) Pembentukan suatu lembaga pemerintah atau assosiasi, Pemerintah bisa memanfaatkan tingginya produksi jagung dan masih besarnya peluang pengembangan komoditi jagung di Provinsi Sulawesi Barat dengan melakukan pembelian jagung atau membangun industri pengolahan yang berbahan dasar jagung. Jika pemerintah melakukan intervensi dengan melakukan pembelian saat harga rendah dengan didukung oleh teknologi penyimpanan untuk menjaga kualitas jagung tetap memenuhi standar atau pembelian untuk bahan baku industri pengolahan jagung oleh Badan Usaha Milik Pemerintah baik oleh Provinsi Sulawesi Barat maupun Kabupaten Mamuju maka stabilitas harga di tingkat petani akan lebih baik dan peningkatan kesejahteraan dari petani jagung bisa dicapai.

b. Ancaman

Faktor-faktor yang menjadi ancaman pemasaran jagung di Kabupaten Mamuju berdasarkan analisis lingkungan eksternal terbagi menjadi lima. Berikut merupakan faktor-faktor yang menjadi ancaman pemasaran jagung di Kabupaten Mamuju:

1) Meningkatnya hasil produksi jagung didaerah lain, masa panen di Provinsi Sulawesi Selatan sangat mempengaruhi harga pembelian jagung di Kabupaten Mamuju. Kualitas yang lebih baik dan rendahnya biaya transportasi untuk jagung asal wilayah Sulawesi Selatan ke kawasan Industri di Makassar menjadikan jagung produksi dari Kabupaten Mamuju menjadi sulit bersaing sehingga harus menerima harga pembelian yang rendah dari pedagang.

2) Adanya import jagung, Import jagung dari luar negeri tentu saja akan mempengaruhi harga di tingkat petani, adanya jagung import dengan harga yang lebih rendah akan membuat penyerapan produk jagung untuk industri semakin menurun. Data tahun 2018 indonesia masih melakukan import jagung sebanyak 737,2 ribu ton (Data BPS) untuk memenuhi kebutuhan industri di dalam negeri.

3) Potensi penurunan kualitas jagung di proses pengiriman, Waktu pembelian dari petani sampai jagung diterima oleh industri jagung yang bisa lebih dari seminggu tentu saja berpotensi mengakibatkan penurunan kualitas dari jagung yang diperdagangkan. Lama waktu penyimpanan digudang, perlakuan jagung dalam proses pengiriman di atas mobil truck, dan kemungkinan terserang kutu saat mobil menunggu di kawasan industri karena berdekatan dengan gudang dedak adalah waktu dimana penurunan kualitas jagung berpotensi terjadi.

4) Harga jagung yang berfluktuasi, permintaan jagung cenderung tinggi untuk keperluan industri, terutama perunggasan, sebagai bahan baku 
pakan ternak. Di sisi lain, petani memiliki posisi tawar yang lemah sehingga harga jagung terus mengalami fluktuasi. Harga dinamis komoditas pertanian berbeda sesuai dengan keberadaan pasar berjangka (Ganneval S, 2016). Harga jagung di Kabupaten Mamuju dipengaruhi oleh beberapa faktor. Faktor yang paling sering mempengaruhi harga jagung di Kabupaten Mamuju adalah waktu panen jagung di daerah daerah di Sulawesi Selatan, jika stok jagung di Sulawesi Selatan berlimpah maka permintaan untuk jagung Mamuju akan menurun sehingga petani harus bersedia menjual jagungnya dengan harga rendah jika hasil panennya ingin diterima oleh industri di Makassar atau Peternak Ayam di Sidrap.

5) Kurangnya lembaga pemodal, Permodalan adalah permasalahan paling mendasar yang sering dihadapi petani. Modal sering menjadi kendala seorang petani dalam melakukan usahataninya. Kurangnya lembaga pemodal menyebabkan petani sangat tergantung pada tengkulak sehingga posisi tawar petani menjadi rendah dalam menjual usahataninya.

\section{B. Formulasi Strategi}

\section{Tahap Input}

a. Matriks External Factor Evaluation (EFE)

Matriks External Factor Evaluation (EFE) merupakan matriks yang berisi data faktor eksternal Pemasaran Jagung di Kabupaten Mamuju berupa peluang dan ancaman yang disusun berdasarkan identifikasi faktor eksternal.

\section{Tabel 5}

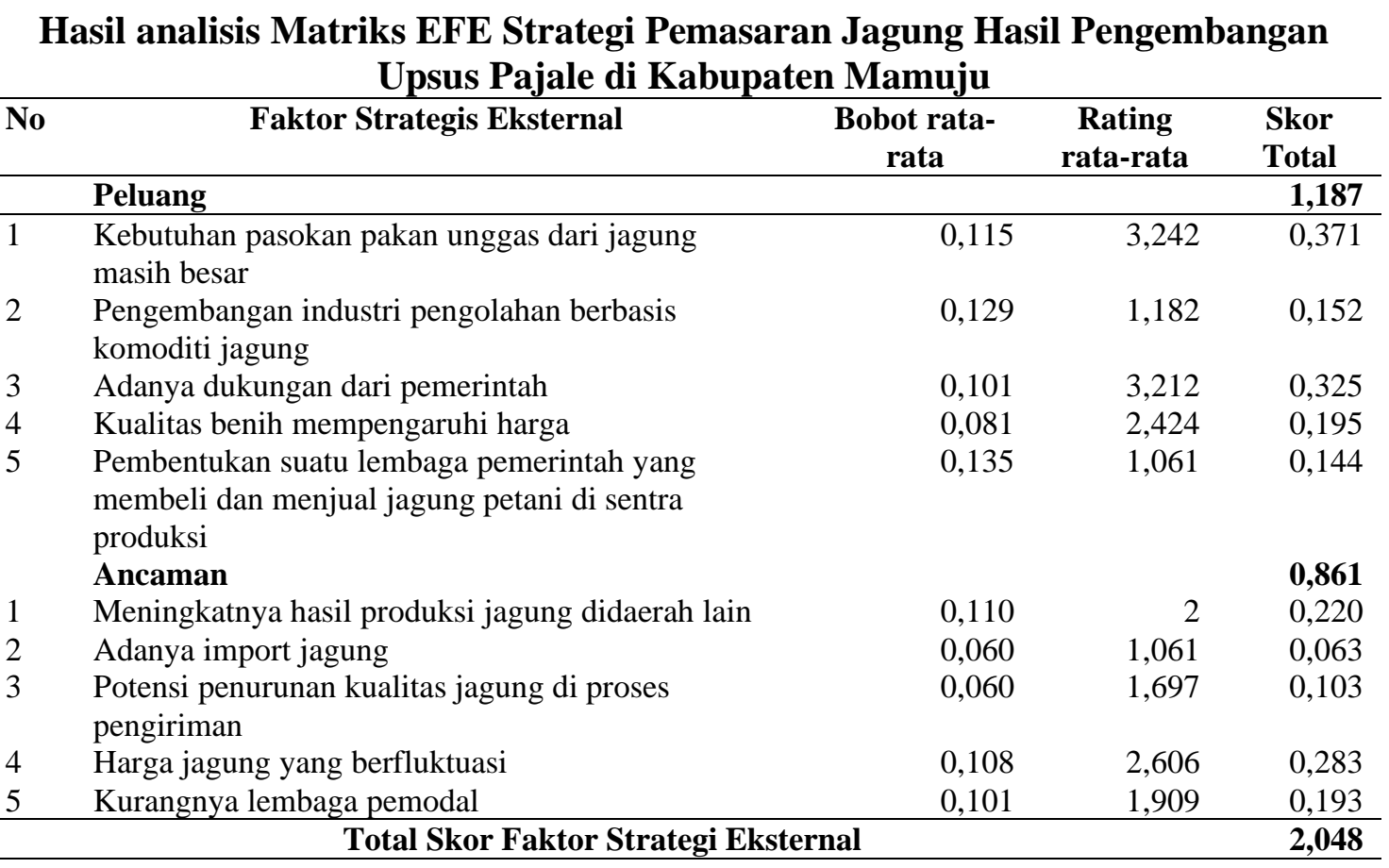


Skor total faktor-faktor kunci eksternal pemasaran jagung di Kabupaten Mamuju yaitu 2.048 sehingga masih berada pada skor di bawah rata-rata. Skor total sebesar 2.048 menunjukkan bahwa pemasaran produk jagung di Kabupaten Mamuju masih dibawah rata-rata dalam menarik keuntungan dari peluang eksternal dan menghindari ancaman yang menghadang. Meski demikian, pemasaran produk jagung masih memiliki ruang yang cukup luas untuk peningkatan, sebab skor bobot total tertinggi yang mungkin adalah 4,0

b. Matriks External Factor Evaluation (EFE)

Matriks Internal Faktor Evaluation (IFE) merupakan matriks yang berisikan faktor internal pemasaran jagung di Kabupaten Mamuju berupa kekuatan dan kelemahan yang disusun berdasarkan identifikasi faktor internal.

\section{Tabel 6}

\section{Hasil analisis matriks IFE Strategi Pemasaran Jagung Hasil Pengembangan Upsus} Pajale di Kabupaten Mamuju

\begin{tabular}{|c|c|c|c|c|}
\hline No & Faktor Strategis Internal & $\begin{array}{c}\text { Bobot } \\
\text { rata-rata }\end{array}$ & $\begin{array}{c}\text { Rating } \\
\text { rata-rata }\end{array}$ & Skor total \\
\hline & Kekuatan & & & 2,191 \\
\hline 1 & Tersedianya sarana perhubungan darat dan laut & 0,111 & 3,970 & 0,440 \\
\hline 2 & $\begin{array}{l}\text { Ketersediaan lahan untuk pertanian jagung yang } \\
\text { luas }\end{array}$ & 0,092 & 3,848 & 0,354 \\
\hline 3 & Jumlah produksi jagung yang tinggi & 0,097 & 3,636 & 0,352 \\
\hline 4 & $\begin{array}{l}\text { Banyaknya pedagang yang bergerak dalam } \\
\text { pemasaran jagung }\end{array}$ & 0,087 & 3,394 & 0,296 \\
\hline 5 & Kelompok tani yang mendukung & 0,089 & 3,545 & 0,315 \\
\hline 6 & Iklim yang sesuai & 0,109 & 3.970 & 0,435 \\
\hline & Kelemahan & & & 0,560 \\
\hline 1 & Prasarana jalan yang kurang memadai & 0,056 & 1,667 & 0,094 \\
\hline 2 & $\begin{array}{l}\text { Posisi tawar petani dalam penentuan harga jagung } \\
\text { rendah }\end{array}$ & 0,063 & 1,061 & 0,066 \\
\hline 3 & Rendahnya kualitas jagung hasil produksi petani & 0,056 & 1,909 & 0,108 \\
\hline 4 & $\begin{array}{l}\text { Terbatasnya tingkat pengetahuan penerapan } \\
\text { teknologi budidaya dan pascapanen }\end{array}$ & 0,056 & 1,788 & 0,100 \\
\hline 5 & Serangan OPT (Organisme Pengganggu Tanaman & 0,087 & 1 & 0,087 \\
\hline 6 & $\begin{array}{l}\text { Belum adanya badan usaha pemerintah yang } \\
\text { menangani pembelian jagung }\end{array}$ & 0,097 & 1,091 & 0,106 \\
\hline \multicolumn{2}{|c|}{ Total Skor Faktor Strategi Internal } & & & 2,752 \\
\hline
\end{tabular}

Skor bobot total faktor-faktor kunci internal Pemasaran Jagung di Kabupaten Mamuju yaitu 2.752 sehingga berada diatas skor rata-rata. Skor bobot total sebesar 2.752 ini menunjukkan bahwa fungsi pemasaran untuk jagung hasil produksi Kabupaten Mamuju memiliki posisi internal yang kuat.

\section{Tahap Input}

a. Matriks Internal External (IE)

Matriks IE merupakan matriks yang menunjukkan posisi produk jagung Kabupaten Mamuju dalam pemasaran yang tergambar dalam 
sembilan sel yang ada dan menunjukkan strategi apa yang dapat diambil berdasarkan posisi sel yang ditempatinya. Matriks IE merupakan tahap penggabungan informasi-informasi yang diperoleh pada tahap input, yaitu matriks IFE dan EFE. Skor bobot total untuk matriks IFE adalah 2.752 sedangkan skor bobot total untuk matriks EFE adalah 2.048 yang menggambarkan bahwa fungsional pemasaran produk jagung di Kabupaten Mamuju berada pada sel V yang artinya berada pada kondisi internal dan eksternal dimana strategi yang dapat diterapkan yaitu konsentrasi melalui Integrasi Horizontal. Strategi ini juga digunakan oleh (Siregar, Surni, \& Indarsyih, 2017) dari penelitiannya yang dilakukan di Desa Oelongko Kabupaten Muna yang juga meneliti mengenai strategi pemasaran jagung dan dari penelitiannya di kabupaten Gianyar mengenai komoditas Padi. Strategi pertumbuhan melalui integrasi horizontal adalah kegiatan yang memperluas perusahaan dengan cara membangun di lokasi yang lain dan meningkatkan produk serta jasa.

Tabel 7

Total Skor Bobot IFE

\begin{tabular}{|c|c|c|c|c|}
\hline 4.0 & $\begin{array}{c}\text { Kuat } \\
3.0-4.0\end{array}$ & $\begin{array}{c}\text { Rata-Rata } \\
2.0-2.99\end{array}$ & Lemah 1.0-1.99 & 1.0 \\
\hline $\begin{array}{l}\text { Tinggi 3.0- } \\
4.0\end{array}$ & \multirow[t]{2}{*}{ I } & \multirow[t]{2}{*}{ II } & \multirow[t]{2}{*}{ III } & \\
\hline 3.0 & & & & \\
\hline $\begin{array}{l}\text { Sedang } \\
2.0-2.99\end{array}$ & \multirow[t]{2}{*}{ IV } & \multirow[t]{2}{*}{ V } & \multirow[t]{2}{*}{ VI } & \\
\hline 2.0 & & & & \\
\hline $\begin{array}{l}\text { Rendah } \\
1.0-1.99 \\
\end{array}$ & \multirow[t]{2}{*}{ VII } & \multirow[t]{2}{*}{ VIII } & \multirow[t]{2}{*}{ IX } & \\
\hline 1.0 & & & & \\
\hline
\end{tabular}

b. Matriks SWOT

Setelah mengetahui posisi perusahaan dengan menggunakan matriks IE, tahap selanjutnya adalah melakukan analisis dengan menggunakan matriks SWOT. (Assauri, 2013) menjelaskan bahwa faktor internal eksternal atau variabel lingkungan internal eksternal perlu dipahami untuk mencapai strategi keunggulan bersaing. Analisis matriks SWOT bertujuan untuk memformulasikan alternatif strategi yang dapat diterapkan untuk produk jagung di Kabupaten Mamuju berdasarkan pengombinasian faktor kunci eksternal (peluang dan ancaman) dan faktor kunci internal (kekuatan dan kelemahan). Selain itu, analisis SWOT yang diformulasikan tetap mempertimbangkan hasil matriks IE dimana kondisi perusahaan yang berada pada sel $\mathrm{V}$ yaitu sebagai perusahaan yang berada pada kondisi internal dan eksternal yang sedang dengan strategi yang dapat digunakan adalah strategi pertumbuhan melalui integrasi horizontal. 


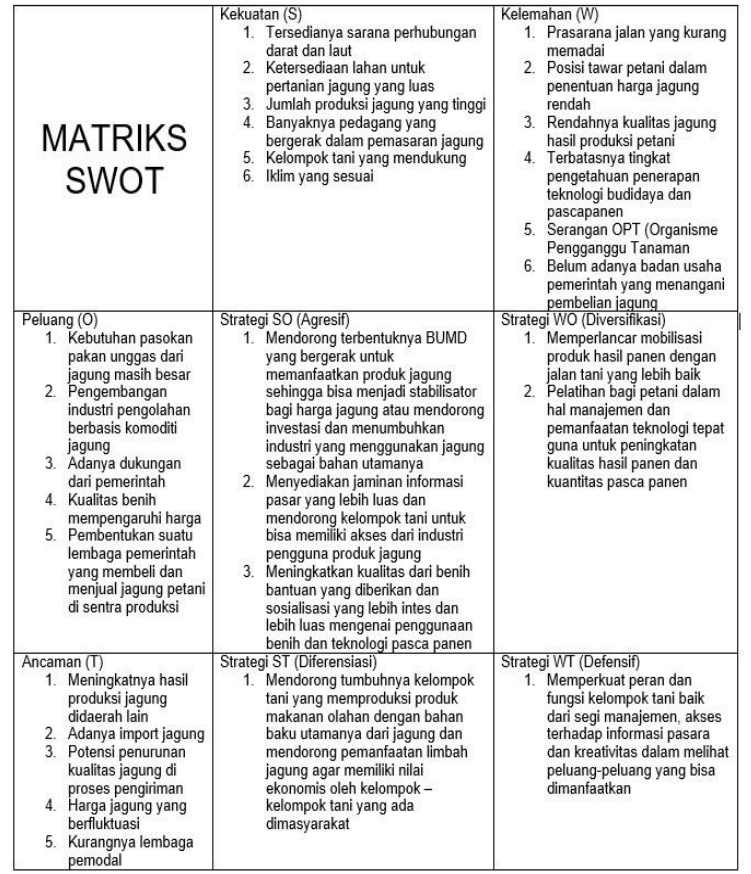

\section{Gambar 1 \\ Matriks SWOT}

Hasil analisis faktor internal dan eksternal yang diolah dengan matriks SWOT diperoleh tujuh alternatif strategi yang dapat dijalankan yaitu:

a. Mendorong terbentuknya BUMD yang bergerak untuk memanfaatkan produk jagung sehingga bisa menjadi stabilisator bagi harga jagung atau mendorong investasi dan menumbuhkan industri yang menggunakan jagung sebagai bahan utamanya.

b. Menyediakan jaminan informasi pasar yang lebih luas dan mendorong kelompok tani untuk bisa memiliki akses dari industri pengguna produk jagung.

c. Meningkatkan kualitas dari benih bantuan yang diberikan dan sosialisasi yang lebih intes dan lebih luas mengenai penggunaan benih dan teknologi pasca panen.

d. Memperlancar mobilisasi produk hasil panen dengan jalan tani yang lebih baik.

e. Pelatihan bagi petani dalam hal manajemen dan pemanfaatan teknologi tepat guna untuk peningkatan kualitas hasil panen dan kuantitas pasca panen.

f. Mendorong tumbuhnya kelompok tani yang memproduksi produk makanan olahan dengan bahan baku utamanya dari jagung dan mendorong pemanfaatan limbah jagung agar memiliki nilai ekonomis oleh kelompok - kelompok tani yang ada dimasyarakat. 
g. Memperkuat peran dan fungsi kelompok tani baik dari segi manajemen, akses terhadap informasi pasara dan kreativitas dalam melihat peluangpeluang yang bisa dimanfaatkan.

\section{Tahap Input (Matriks QPSM)}

Tahap pengambilan keputusan merupakan tahapan untuk menentukan strategi mana yang terbaik yang harus diambil. Matriks QSPM merupakan salah satu alat untuk menentukan prioritas strategi dari alternatif strategi yang didapat lewat matriks SWOT. Tujuh alternatif strategi yang didapat dari matriks SWOT dimasukan kedalam matriks QSPM untuk ditentukan skor daya tarik setiap strategi (AS) dan skor total daya tarik dari setiap strategi (TAS). Skor AS dan TAS diperoleh berdasarkan penilaian dari tiga puluh tiga responden yaitu lima orang pedagang jagung, sepuluh orang ketua kelompok usaha tani jagung, lima belas orang petani jagung dan tiga orang pengambil kebijakan. Berdasarkan hasil perhitungan dan analisis QPSM yang dilakukan, diperoleh urutan priortas strategi pemasaran jagung hasil penembangan UPSUS PAJALE di Kabupaten Mamuju seperti terlihat pada tabel 13. Tiga prioritas strategi yang ditemukan dalam penelitian ini adalah 1). Mendorong terbentuknya BUMD yang bergerak untuk memanfaatkan produk jagung sehingga bisa menjadi stabilisator bagi harga jagung atau mendorong investasi dan menumbuhkan industri yang menggunakan jagung sebagai bahan utamanya, 2). Memperkuat peran dan fungsi kelompok tani baik dari segi manajemen, akses terhadap informasi pasara dan kreativitas dalam melihat peluang-peluang yang bisa dimanfaatkan dan 3). Menyediakan jaminan informasi pasar yang lebih luas dan mendorong kelompok tani untuk bisa memiliki akses dari industri pengguna produk jagung.

\section{Tabel 8}

\section{Strategi pemasaran jagung fasil pengembangan UPSUS PAJALE di Kabupaten} Mamuju dari matriks QSPM

\begin{tabular}{lcc}
\hline \multicolumn{1}{c}{ Alternatif Strategi } & $\begin{array}{c}\text { Total Nilai } \\
\text { Daya Tarik }\end{array}$ & $\begin{array}{c}\text { Urutan } \\
\text { Prioritas }\end{array}$ \\
\hline $\begin{array}{l}\text { Mendorong terbentuknya BUMD yang bergerak untuk } \\
\text { memanfaatkan produk jagung sehingga bisa menjadi } \\
\text { stabilisator bagi harga jagung atau mendorong investasi dan } \\
\text { menumbuhkan industri yang menggunakan jagung sebagai } \\
\text { bahan utamanya }\end{array}$ & 6,545 & 1 \\
\hline $\begin{array}{l}\text { Menyediakan jaminan informasi pasar yang lebih luas dan } \\
\text { mendorong kelompok tani untuk bisa memiliki akses dari } \\
\text { industri pengguna produk jagung }\end{array}$ & 5,189 & 3 \\
\hline $\begin{array}{l}\text { Meningkatkan kualitas dari benih bantuan yang diberikan } \\
\text { dan sosialisasi yang lebih intes dan lebih luas mengenai } \\
\text { penggunaan benih dan teknologi pasca panen }\end{array}$ & 5,099 & 4 \\
\hline $\begin{array}{l}\text { Memperlancar mobilisasi produk hasil panen dengan jalan } \\
\text { tani yang lebih baik }\end{array}$ & 4,100 & 7 \\
\hline $\begin{array}{l}\text { Pelatihan bagi petani dalam hal manajemen dan } \\
\text { pemanfaatan teknologi tepat guna untuk peningkatan } \\
\text { kualitas hasil panen dan kuantitas pasca panen }\end{array}$ & 4,500 & 6 \\
\hline \begin{tabular}{l} 
Mendorong tumbuhnya kelompok tani yang memproduksi \\
\hline
\end{tabular} & 4,942 & 5 \\
\hline
\end{tabular}




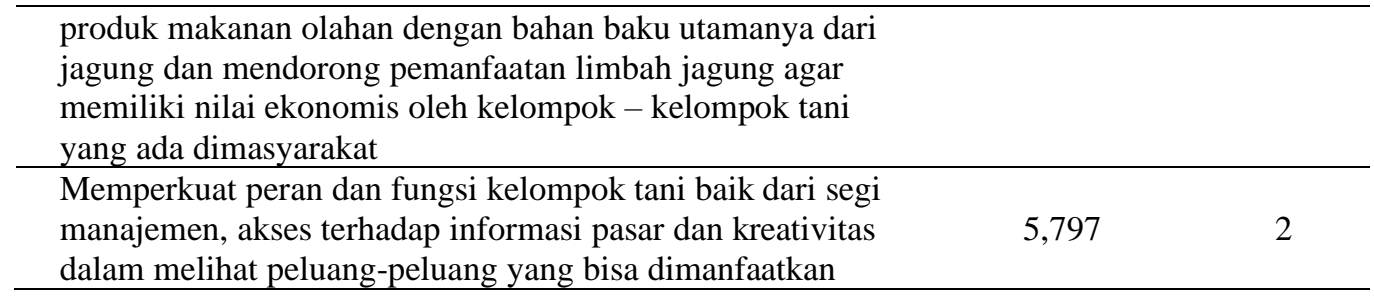

\section{Kesimpulan}

Terdapat 12 faktor eksternal dan 10 faktor internal yang mempengaruhi pemasaran jagung di Kabuapten Mamuju. Faktor internal: tersedianya sarana perhubungan darat dan laut, ketersediaan lahan untuk pertanian jagung yang luas, jumlah produksi jagung yang tinggi, banyaknya pedagang yang bergerak dalam pemasaran jagung, kelompok tani yang mendukung, iklim yang sesuai, prasarana jalan yang kurang memadai, posisi tawar petani dalam penentuan harga jagung rendah, rendahnya kualitas jagung hasil produksi petani, terbatasnya tingkat pengetahuan penerapan teknologi budidaya dan pascapanen, serangan OPT (Organisme Pengganggu Tanaman) dan belum adanya badan usaha pemerintah yang menangani pembelian jagung. Faktor eksternal: Kebutuhan pasokan pakan unggas dari jagung masih besar, pengembangan industri pengolahan berbasis komoditi jagung, adanya dukungan dari pemerintah, kualitas benih mempengaruhi harga, pembentukan suatu lembaga pemerintah yang membeli dan menjual jagung petani di sentra produksi, meningkatnya hasil produksi jagung didaerah lain, adanya import jagung, potensi penurunan kualitas jagung di proses pengiriman, harga jagung yang berfluktuasi dan kurangnya lembaga pemodal.

Berdasarkan hasil yang diperoleh dari SWOT dan pengolahan QSPM, diperoleh tiga strategi prioritas untuk pemasaran jagung hasil UPSUS PAJALE di Kabupaten Mamuju yaitu: a). Mendorong terbentuknya BUMD yang bergerak untuk memanfaatkan produk jagung sehingga bisa menjadi stabilisator bagi harga jagung atau mendorong investasi dan menumbuhkan industri yang menggunakan jagung sebagai bahan utamanya, b). Memperkuat peran dan fungsi kelompok tani baik dari segi manajemen, akses terhadap informasi pasara dan kreativitas dalam melihat peluang-peluang yang bisa dimanfaatkan, c). Menyediakan jaminan informasi pasar yang lebih luas dan mendorong kelompok tani untuk bisa memiliki akses dari industri pengguna produk jagung. 


\section{BIBLIOGRAFI}

Ariusni, Ariusni, \& Sentosa, Sri Ulfa. (2018). Rekayasa Pengembangan Pasar Jagung di Sentral Produksi Jagung Sumatera Barat. Google Scholar

Assauri, S. (2013). Manajemen Pemasaran, edisi 1 cetakan 12. Rajawali Grafindo (Rajawali Pers), Jakarta. Google Scholar

Badan Penyuluhan dan Pengembangan SDM Pertanian. (2015). Petunjuk Pelaksanaan Pengawalan dan Pendampingan Penyuluh di Lokasi Sentra Padi Jagung dan Kedelai. Jakarta: Kementerian Pertanian.

Badan Pusat Statistik. (2020). Kota Sibolga dalam Angka 2020. sibolga: BPS.

David, Fred R., \& David, Forest R. (2016). Manajemen strategik: Suatu pendekatan keunggulan bersaing. Jakarta: Salemba Empat. Google Scholar

David RF. (2012). Manajemen Staregik. Jakarta: Salemba Empat.

Ganneval S. (2016). Spatial Price Transmission on Agricultural Commodity Markets under Different Volatility Regimes. Econ Modelling [Internet]. https://doi.org/http://dx.doi.org/10.1016/j.econmod. 2014.11. 027 Google Scholar

Kango, Umin. (2018). Strategi Pemasaran Jagung Gorontalo Sebagai Program Unggulan Daerah. Jambura: Jurnal Ilmiah Manajemen Dan Bisnis, 1(3), 366-391. Google Scholar

Kotler, Philip, Kartajaya, H., \& Setiawan, I. (2017). Marketing 4. O. 0: Moving from Traditional to Digital. New York: John Wiley \& Sons. Google Scholar

Rangkuti, F. (2013). Riset Pemasaran, Cetakan 11, PT. Gramedia Pustaka Utama, Jakarta. Google Scholar

Siregar, Wa Ode Fifi Sofiani, Surni, Surni, \& Indarsyih, Yusna. (2017). Strategi Pemasaran Jagung di Desa Oelongko Kecamatan Bone Kancitala Kabupaten Muna. Jurnal Ilmiah Agribisnis, 2(1), 281398. Google Scholar

Sugiyono. (2017). Metode Penelitian Kuantitatif, Kualitatif dan R\&D. Bandung: PT Alfabet.

Sugiyono. (2017). Metode Penelitian Kuantitatif, Kualitatif Dan R\&D. Bandung: PT Alfabet.

Syamsuddin dan Rahmawati. (2015). Trend Produksi dan Target Pengembanagn Mendukung Swasembada jagung Berkelanjutan Di Sulawesi Barat. Prosiding Seminar nasional Serealia.

Titik, Wijayanti. (2012). Marketing Plan dalam bisnis. Elex Media Komputindo. 
Strategi Pemasaran Jagung Hasil Pengembangan Upsus Pajale Di Kabupaten Mamuju

Jakarta. Google Scholar

\section{Copyright holder:}

Zulfiani Effendi, Ahmad Ramadhan Siregar, Sitti Nurani Sirajuddin (2021)

First publication right:

Syntax Literate: Jurnal Ilmiah Indonesia

This article is licensed under:

(c) (i) (O) 